\title{
A review framework of how earthquakes trigger volcanic eruptions
}

\author{
Gilles Seropian (10 ${ }^{1 凶}$, Ben M. Kennedy (1) ${ }^{1}$, Thomas R. Walter ${ }^{2}$, Mie Ichihara $^{3}$ \& \\ Arthur D. Jolly ${ }^{4}$
}

It is generally accepted that tectonic earthquakes may trigger volcanic activity, although the underlying mechanisms are poorly constrained. Here, we review current knowledge, and introduce a novel framework to help characterize earthquake-triggering processes. This framework outlines three parameters observable at volcanoes, namely magma viscosity, open- or closed-system degassing and the presence or absence of an active hydrothermal system. Our classification illustrates that most types of volcanoes may be seismically-triggered, though require different combinations of volcanic and seismic conditions, and triggering is unlikely unless the system is primed for eruption. Seismically-triggered unrest is more common, and particularly associated with hydrothermal systems.

$\mathrm{V}$ olcanic eruptions and earthquakes are amongst the most spectacular and sometimes deadliest natural events occurring on our planet, fascinating humans for centuries, with records extending to ancient times ${ }^{1-3}$. One naturally arising question is whether tectonic earthquakes can trigger volcanic eruptions, referred to as earthquake-volcano interactions ${ }^{4}$ or seismically triggered eruptions ${ }^{5,6}$. The statistical record of seismically triggered eruptions shows it is a relatively rare occurrence ${ }^{7,8}$, but understanding the causal relationships between earthquakes and volcanoes is essential towards more efficient hazard management approaches. A number of articles have summarized recent concepts and observations of earthquake-volcano interactions, including Hill et al. ${ }^{4}, K^{2}$ oyama ${ }^{9}$, Manga and Brodsky ${ }^{6}$, Eggert and Walter ${ }^{10}$ and Watt et al. ${ }^{11}$. We herein provide a framework for using their findings and highlight recent advances. Our motivation is to identify which types of volcanoes are more susceptible to seismic triggers.

Volcanoes display an immense diversity in subsurface and aerial structure, style of eruption, chemical composition or precursory signals. As a result, the underlying seismic-triggering mechanisms may vary from one seismically triggered eruption to another. Latter ${ }^{12}$ already noted in 1971 that "the process is neither universal nor invariable". Besides, earthquakes may even inhibit volcanic activity in some conditions ${ }^{9,13-15}$. Hence, can we identify and classify volcanoes based on their sensitivity to seismic-triggering mechanisms? A common method is to devise a classification of volcanoes based on historical records: if a given type of volcano erupts more frequently after earthquakes, then it is considered more sensitive $e^{8,9,16,17}$. Unfortunately, the limited number of recorded events precludes statistically significant correlations for most volcanoes ${ }^{8}$.

\footnotetext{
${ }^{1}$ School of Earth and Environment, University of Canterbury, Christchurch, New Zealand. ${ }^{2}$ GFZ German Research Center for Geosciences, Potsdam, Germany. ${ }^{3}$ Earthquake Research Institute, University of Tokyo, Bunkyo-ku, Tokyo, Japan. ${ }^{4}$ GNS Science, Lower Hutt, New Zealand. ${ }^{凶}$ email: gilles. seropian@pg.canterbury.ac.nz
} 
In this contribution, we adopt a new strategy where we start from the underlying physical mechanisms in order to derive our classification. By considering the favourable conditions for each mechanism, we construct a series of different volcano types, with each one being sensitive to different mechanisms. We then examine different earthquake scenarios and the control they exert on triggering dynamics. We thus produce a novel classification of volcanoes, according to how they can be seismically triggered aimed at informing future monitoring or statistical efforts.

\section{Background}

Observations. The oldest and commonest evidence of earthquake-volcano interactions is serendipitous observation ${ }^{18-21}$. These potentially coincidental observations later evolved into accurate records combining multiple geophysical signals ${ }^{10}$, permitting more precise correlations ${ }^{22-25}$. In particular, the recent emergence of satellite monitoring as a reliable tool in geosciences allowed for a more systematic and consistent monitoring of volcanoes globally ${ }^{17,26-28}$. The influence of an earthquake on an eruption can also be inferred a posteriori from crystal textures ${ }^{29-31}$. Like other authors, we emphasize that a spatio-temporal correlation between seismic and volcanic events does not necessarily imply a causal relationship. Two concurrent events could result from a common third underlying process, or occur by chance. Yet observing a correlation is a necessary first step in unravelling a potential causal relationship.

There are documented cases of both changes from quiescence to eruption $6,20,29,32-35$, and changes in style of an ongoing eruption $^{36-40}$ in the weeks following an earthquake. Earthquakes may also trigger a broad spectrum of non-eruptive unrest phenomena including increased seismicity ${ }^{25,41-45}$, degassing ${ }^{17,25,34,46,47}$, heat flux ${ }^{26-28,48}$ or subsidence ${ }^{49,50}$. Hydrothermal systems are particularly sensitive to seismic stimuli, with many reports of increased activity following earthquakes $6,51-55$.

Statistical inference. Statistical tests are a crucial step to assess whether eruptions follow earthquakes due to significant coupling or simply by coincidence. Determining the temporal and spatial extent of earthquakes' impact on volcanoes also helps to constrain plausible mechanisms and inform hazard models. The historical earthquake and eruption records are regarded to be complete only in the most recent period (1960s-present) ${ }^{8,56}$. As a result, the sample size (i.e. number of events considered) is quite small, decreasing the robustness of statistical tests.

The early statistical groundwork on a global scale $e^{5,6,10,56,57}$ was updated by Sawi and Manga $^{8}$ who conclude that the apparent correlations within a few days occur most likely due to chance.
Yet, there exists a slight but significant increase in eruption rate in the 2-5 years period following an earthquake on a global scale $8,33,56$. Statistical tests perform better on regional scales, in particular in active subduction zones 8,10 . This is supported by detailed studies of the Chilean $^{11,16}$, Japanese ${ }^{58}$ and Indonesian ${ }^{7,33}$ subduction zones which all show increased eruption rates-to various degrees-following large magnitude earthquakes. Ultimately, the internal state of the volcano-whether it is "ready" to erupt-dictates whether it will be seismically triggered or not ${ }^{7}$. This association may thus simply reflect the fact that subduction zones feature the highest concentration of large earthquakes and volcanoes on the verge of erupting 7 .

The maximum distance at which eruptions may be seismically triggered is debated. Delle Donne et al. ${ }^{27}$ propose a distance-magnitude relationship, akin to what is found in the mud volcanism and soil liquefaction literature ${ }^{59,60}$. For triggerederuptions stricto sensu, Nishimura ${ }^{56}$ suggests a limit of about 200 $\mathrm{km}$ from the epicentre, whereas Marzocchi et al. ${ }^{61}$ propose 1000 $\mathrm{km}$. Concerning triggered-unrest, earthquake-induced thermal anomalies $^{27,28}$ and seismicity ${ }^{62}$ are both reported at distances over $10,000 \mathrm{~km}$. This matches observations of seismically induced changes in groundwater level or streamflow ${ }^{63}$.

\section{Triggering mechanisms}

A wide range of triggering mechanisms have been proposed, affecting the host rock, magma chamber and/or hydrothermal system, causing stress changes in solid state and dynamic variations in fluid and multiphase systems ${ }^{4,6,9,64}$. Earthquakes result from sudden ruptures in the crust, and cause significant changes in the surrounding stress field. We must thus investigate how stress perturbations affect magmatic systems in order to understand how this may eventually lead to an eruption. Stress can be transferred either statically or dynamically (Fig. 1), which will in turn dictate what triggering mechanisms can occur. We now examine both cases.

Static processes. Static stress changes result from the deformation of rocks following an earthquake ${ }^{65}$ (Fig. 1). The resultant strain is spatially confined to within a few fault lengths around the epicentre and remains until the stress is elastically released or dissipated by ductile flow. Static stress changes can be either compressive or extensional, both of which might promote eruption $^{9,56}$.

Extensional stresses facilitate dyke opening by "unclamping" the system (Fig. 2), thus promoting magma transport and potentially triggering an eruption $16,29,32,33,66-75$. If the magma already contains bubbles, then reduced compression could result

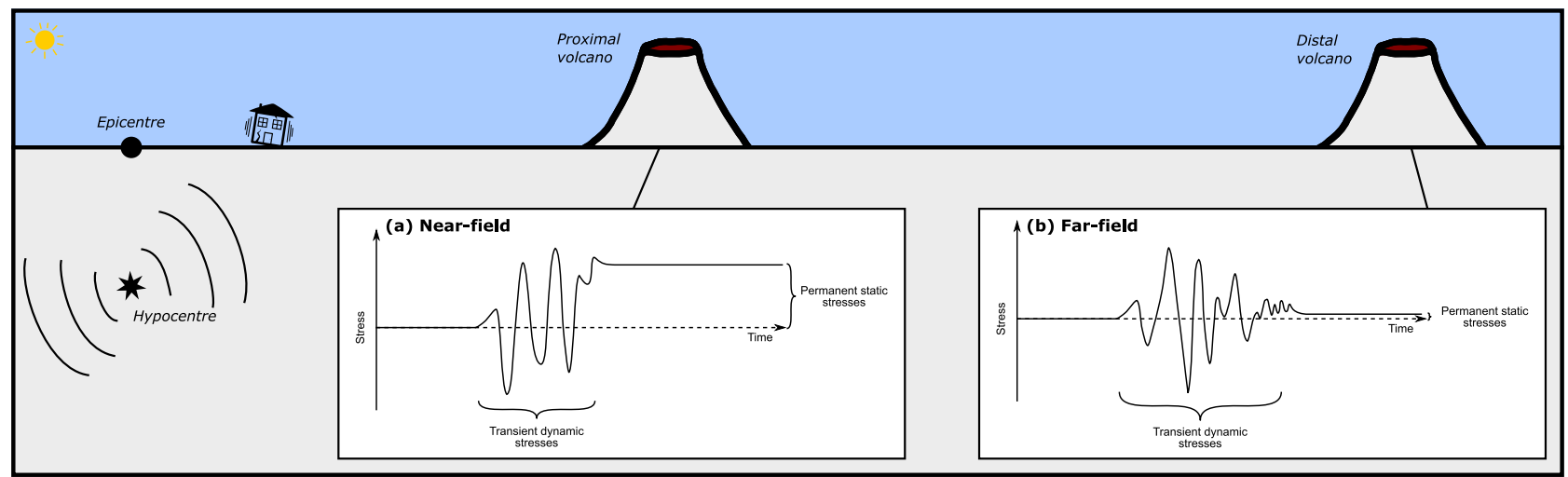

Fig. 1 The difference between dynamic and static stresses. Dynamic stresses are transient, whereas static stresses last permanently. a In the region close to the epicentre, dynamic and static stresses have similar amplitudes. b Far from the epicentre, however, dynamic stresses have a much larger amplitude and static stresses are negligible. 


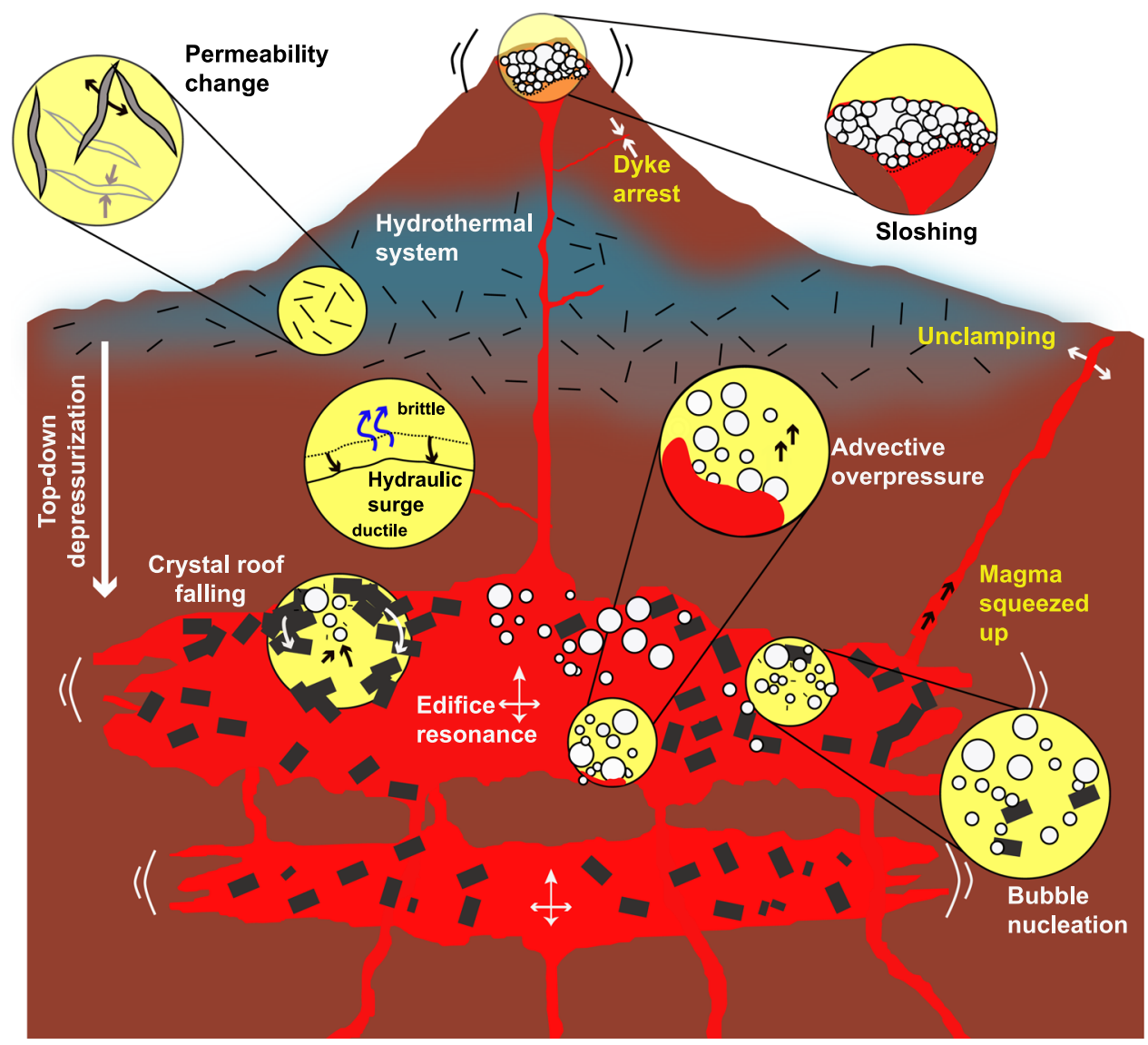

Fig. 2 The most common seismic-triggering mechanisms. Mechanisms names in yellow are due to static stresses whereas those in black and white arise from dynamic stresses.

in overpressure ${ }^{76,77}$. Additionally, extension favours strike-slip faulting and increased permeability ${ }^{78,79}$, thus allowing increased advection of magmatic fluids and melt 15,78 .

Compressional stresses have been conceptualized to squeeze magma upwards ${ }^{13,66,67,80-83}$ (Fig. 2), though this process has been criticized $^{84}$. Conversely, compression at shallow depths has been inferred to inhibit and arrest dyke propagation ${ }^{9,14,85-87}$, and thus prevent eruption. We emphasize that the orientation of volcanic structures relative to stresses is critical to these models.

Seismic stresses are eventually dissipated by viscous flow of the lower lithosphere and asthenosphere ${ }^{88,89}$. This process happens over years to decades. This slow relaxation of underlying layers will impose "quasi-static" stress changes on the overlying, brittle lithosphere. These quasi-static stress changes have also been postulated to favour volcanic eruptions ${ }^{4,61}$, though the physical mechanism(s) require further study.

Dynamic processes. Dynamic stresses involve the oscillatory stresses induced by seismic waves ${ }^{90}$ (Fig. 1). The amplitudes of dynamic stresses decrease much more gradually with distance than their static counterparts, hence dynamic stresses will generally (1) be greater and (2) travel much further than static stresses $^{6,90-92}$. However, dynamic stresses are oscillatory phenomena, and thus feature a range of characteristic frequencies and are transient. Responses to dynamic stresses can be broadly divided into three categories.

Volatile processes. Volatiles have the lowest viscosities of all volcanic fluids (as low as $10^{-5} \mathrm{~Pa} . \mathrm{s}$ ), high compressibility, and can thus respond quickly to dynamic stresses. Three mechanisms associated with volatiles could lead to an eruption, namely (1) bubble nucleation and growth, (2) advective overpressure associated with bubble rise and (3) falling crystal roofs facilitating vesiculation (Fig. 2).

Dynamic stresses could induce bubble nucleation in magmas $^{6,23}$ by varying the local pressure. The phenomenon is well known in other fluids, in particular in water ${ }^{93}$, and usually referred to as cavitation. Static decompression may sometimes be sufficient to trigger nucleation $23,33,35$. Pressure oscillations in the fluid can locally change the solubility and diffusivity of volatiles (mostly water), thus accelerating bubble formation processes. The phenomenon was experimentally demonstrated for groundwater ${ }^{94}$. Bubble nucleation in magma, however, is a very complex process, depending upon many parameters ${ }^{95}$ (e.g., volatile oversaturation, melt composition, presence of nucleation sites). For instance, it is notoriously difficult to nucleate bubbles experimentally in crystal poor rhyolite ${ }^{96}$, sometimes requiring immense pressure drops $>100 \mathrm{MPa}$, much larger than seismic dynamic stresses ${ }^{6,90}$ (generally $<10 \mathrm{MPa}$ ). With abundant nucleation sites, however, a few MPa may be sufficient to induce bubble nucleation $^{97,98}$. To the best of our knowledge, there is no available experimental evidence showing that pressure oscillations can induce bubble nucleation in silicate melts.

Magma often already contains bubbles, in which case problems related to nucleation become irrelevant. Dynamic stresses may then accelerate volatile diffusion and bubble growth. Rectified diffusion is a very commonly cited mechanism where seismic waves enhance diffusion of volatiles inside the bubbles ${ }^{99-101}$ but its effects have initially been overestimated, and it is now considered most likely inefficient in magma ${ }^{6,102}$. We will then not consider rectified diffusion further in this contribution. Other dynamic mechanisms that could facilitate bubble growth and 
coalescence include Ostwald ripening ${ }^{103,104}$ or advection due to Bjerknes force ${ }^{105}$, but they have not been considered under the lens of earthquake-volcano interactions yet.

A further mechanism related to bubbles is advective overpressure $^{106,107}$ (Fig. 2). Here, it is considered that bubbles that were previously held down to the reservoir floor or walls by surface tension can be shaken loose by seismic waves. Assuming an incompressible fluid, a closed system with undeformable walls and no mass exchange between the bubbles and the melt, the bubbles can carry large overpressures with them while rising ${ }^{106,108,109}$. Nevertheless, this mechanism has been heavily debated $^{110,111}$ because most of the assumptions are unrealistic for a magmatic reservoir. Advective overpressure could still be effective in hydrothermal and hydrogeological systems however ${ }^{53,54,107,112}$. It is also possible that seismic waves increase bubble rise ascent speed, as shown by preliminary results from analogue experiments in shear thinning fluids ${ }^{113,114}$.

Finally, seismic waves could dislodge crystal aggregates that accumulate on top of a magma reservoir ${ }^{4,6}$ (Fig. 2). Upon detaching, dense crystals will sink and lighter melt will rise to replace them. Upwelling melt is then prone to vesiculation, which could in turn lead to an eruption. Preliminary calculations ${ }^{4,6}$ showed the mechanism to be theoretically realistic, but it will require further work to demonstrate that (a) these crystal roofs exist, (b) characterize their rheology and (c) validate the theory used to describe sinking of crystal plumes.

Resonance processes. The second category of mechanisms relates to the mechanical sway of magma in response to shaking. The amount of movement will depend on a number of parameters, including the resonant frequency of the system, mainly controlled by the edifice dimensions and reservoir geometry. If the seismic waves match this frequency, the processes will be greatly enhanced; otherwise effects will be negligible. Two resonance mechanisms have been proposed, namely sloshing and edifice resonance (Fig. 2).

Seismic waves can induce sloshing in the reservoir ${ }^{115}$. Sloshing refers to the movement of a fluid inside its container ${ }^{116-118}$-here magma in its reservoir. Sloshing of a foam layer in a magmatic reservoir or conduit could lead to foam collapse, increased degassing and vesiculation, potentially forming gas slugs and Strombolian eruptions ${ }^{115}$. Analogue experiments show that foam collapse will only occur if (1) the incident seismic waves carry significant energy around the reservoir's resonance frequency to initiate sloshing and (2) a magma foam is present with a free top surface or is overlying a deeper dense melt region ${ }^{115}$. The mechanism will further be facilitated by a foam featuring a high bubble fraction, large bubbles and low melt viscosity.

Seismic waves can also increase melt and volatile migration inside a volcanic edifice ${ }^{119}$. A combination of analogue and numerical models show that shaking will accelerate fluid movement in either direction (upwards, downwards or laterally) depending upon the fluid buoyancy and storage depth ${ }^{119}$. Lighter (in particular bubble rich) and shallower fluids will tend to move upwards. The phenomenon is again greatly enhanced when the seismic waves resonate with the edifice. Thus, edifice resonance may either favour eruption by facilitating magma mobilization upwards or retard an eruption by forcing magma downwards ${ }^{119}$.

Hydrothermal system triggering. Hydrothermal and geothermal systems have been observed to be extremely sensitive to earthquakes and dynamic stresses in particular6,15,41,51,52,54,90,120-132. Hydrothermal systems are also generally well connected to the underlying magmatic reservoir ${ }^{133,134}$, hence destabilization may lead to a top-down depressurization of the entire magmatic system, and eventually magmatic eruption ${ }^{4,15,135-138}$ (Fig. 2). The possibility for hydrothermal systems to form a link between seismic waves and magmatic reservoir destabilization has received little attention under the lens of seismic triggers $4,83,138$ but observations ${ }^{15,34,42,127}$ suggest that it could play a major role. The triggering mechanisms of hydrothermal systems generally fall into two categories: change in fluid pressure and change in permeability.

The physical models describing changes in fluid pressure in hydrothermal systems are similar to the ones described in section "Volatile processes". The main mechanisms are bubble nucleation $^{94}$ and advective overpressure ${ }^{54,107,112}$. Here, however, the main fluid is water, with a viscosity of $10^{-3}$ Pa.s. Additionally, the gas phase is generated by evaporation instead of volatile diffusion in the liquid phase. These features allow for much faster kinetics and less viscous dissipation, making these mechanisms more efficient in hydrothermal settings.

Seismic waves can significantly alter permeability over short time-intervals ${ }^{59,139}$ (Fig. 2). Such changes have been particularly well observed in hydrogeologic systems ${ }^{140}$, with sudden variations in streamflow ${ }^{141,142}$, groundwater level ${ }^{143-147}$, temperature ${ }^{148-150}$ and seismically triggered mud volcanism ${ }^{6,60,151-153}$. With increased permeability, regions of higher and lower pressures may become connected, allowing fluid flow and pore pressure redistribution ${ }^{59,63}$. The sudden influx of fluids into originally lowpressure zones, may push such regions beyond a critical pressure threshold and produce an eruption ${ }^{120}$. On the other hand, reduced permeability allows local pressurization, which may lead to fragmentation and eruption ${ }^{154,155}$. The mechanisms described hereafter are particularly attractive because they necessitate relatively small $(<1 \mathrm{MPa})$ dynamic stresses, and may thus be triggered more easily ${ }^{59}$. Three mechanisms are often invoked to explain changes in permeability.

Firstly, seismic waves may unclog or clog fractures ${ }^{156-160}$. The passage of seismic waves may intensify fluid flow, which could in turn entrain small particulates resulting in both clogging ${ }^{160}$ and unclogging ${ }^{156}$ downstream depending on fracture orientations.

Dynamic stresses may also enhance or reduce permeability by opening, closing or shearing cracks ${ }^{15,132,141,161-163}$. Opening new cracks or widening already existing ones increases permeability whereas other fractures with less favourable orientations would be closed and hence decrease permeability.

Finally, seismic waves may lower the brittle-plastic transition between the hydrothermal and magmatic systems ${ }^{4,137}$ (Fig. 2). For this scenario, we assume that there exists an impermeable plastic transition zone underlying the hydrothermal system retaining pressurized fluids ${ }^{164}$. In this case, the strain rates imposed by seismic waves may be sufficient to promote brittle behaviour and release overpressurized fluids into the hydrothermal system (referred to as a hydraulic surge ${ }^{4}$ ), favouring unrest and eruption ${ }^{4,137}$.

External triggers. Earthquakes can also trigger eruptions indirectly via external triggers. These occur when an earthquake triggers a non-volcanic event which then cascades towards an eruption. A typical example is that of an earthquake triggering a landslide or block and ash flow above a critically pressured magmatic reservoir or dome $\mathrm{e}^{165-167}$. The resulting sudden decompression may lead to eruption of magma. Another documented external trigger is via crust decarbonation ${ }^{40}$. Earthquakes induce cracking in the crust underlying the magmatic reservoir, thus releasing important volumes of $\mathrm{CO}_{2}$. $\mathrm{CO}_{2}$ then flushes the reservoir, significantly lowering the solubility of water, hence triggering vesiculation, pressurization and eventually producing the observed changes in eruption style. While it is important to explore the possible feedbacks between magmatic systems and 
Table 1 The five most common volcano types according to our classification.

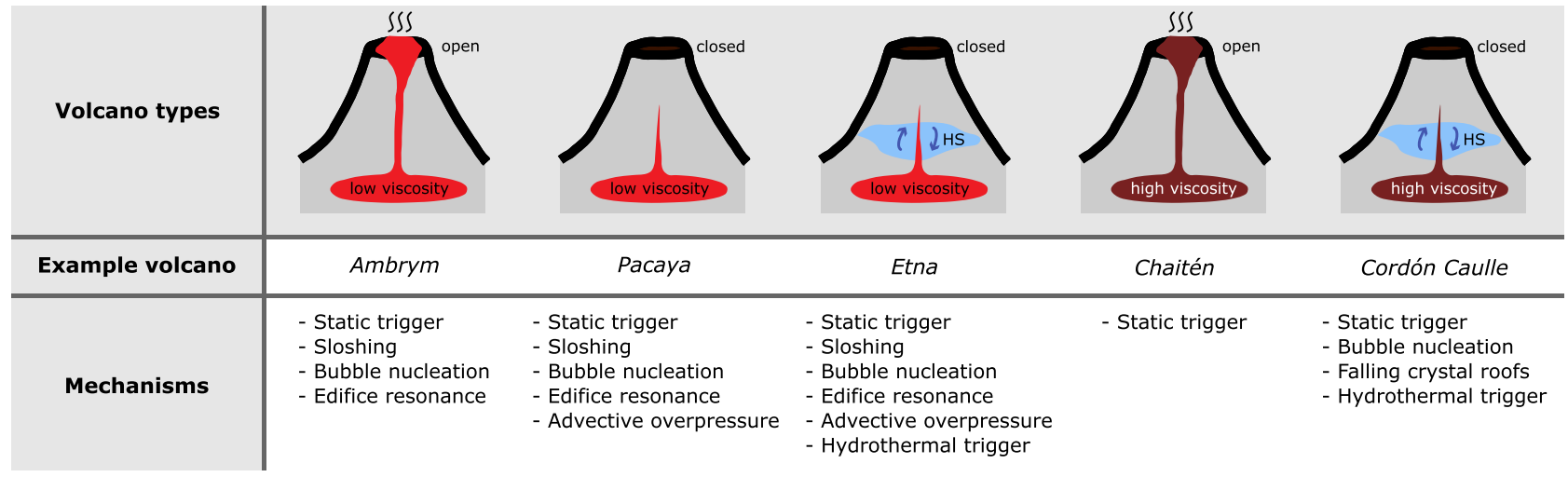

For each type, we propose a natural example and list the possible triggering mechanisms. The three volcanic criteria are indicated with text and a diagram: (1) bright red stands for low viscosity, dark red corresponds to high viscosity, (2) a conduit extending to the surface represents open system whereas a conduit stopping at depth represents closed system, (3) the presence of a hydrothermal system is indicated by the initials "HS" and a blue region with circular arrows above the magma chamber, the lack thereof indicates absence of a hydrothermal system.

their environments, we will not consider external triggers further, and solely focus on direct interactions between earthquakes and magmatic systems.

External triggers hence have the potential to trigger eruptions in many possible ways, it is thus important to explore, in the future, the possible feedbacks between an igneous system, its hydrothermal and their mechanical environment when subjected to an earthquake.

\section{Volcano types}

For each mechanism, there is a set of favourable physical parameters maximizing triggering efficiency. They can be divided in two categories: (1) volcanic (e.g. melt viscosity) and (2) seismic (e.g. seismic wave frequency). We examine volcanic parameters first.

Our choice of parameters is developed by capturing both the important complexity associated with the mechanisms whilst remaining simple enough to be applied. From section "Triggering mechanisms", we see that two parameters, namely magma viscosity and whether the system is open or closed, play critical roles for many mechanisms. The sensitivity of hydrothermal systems make them the key third parameter to be. It is interesting to note that this choice of parameters which naturally arises from our analysis resembles other recent volcano classifications ${ }^{168,169}$, despite the different objectives. Our classification currently focuses on subaerial volcanism only. Seismic events do trigger various responses from submarine volcanoes ${ }^{33,170-172}$; however, the current amount of available data are too scarce to be fitted in our classification.

The first parameter is magma viscosity, for which we will consider two limiting cases, namely low and high viscosity. Low viscosities generally correspond to basaltic, crystal poor magma, and are lower than or equal to $\sim 10^{4} \mathrm{~Pa} . \mathrm{s}^{173,174}$. We delineate high viscosities as greater than or equal to $\sim 10^{5} \mathrm{~Pa}$.s and can be achieved by rhyolitic melt, or through the addition of suspended crystals and bubbles ${ }^{175,176}$. Other parameters such as water content or temperature also exert significant control on viscosity. This simplified classification does overlook some major rheological properties (e.g. non-Newtonian behaviour ${ }^{177,178}$ ) yet captures the magma properties that favour certain mechanisms. For instance, it is very unlikely for a magma with viscosity $10^{5} \mathrm{~Pa}$.s to ever experience sloshing, but one with viscosity $10^{1} \mathrm{~Pa}$.s will.

The second parameter is whether the system is open or closed to degassing. Open systems are permeable and volatiles can easily escape as bubbles, directly out of magma or through fractures. In contrast, in a closed system, permeability is low and volatiles are trapped and cannot leave. It is quite rare for a volcano to display pure open- or closed-system degassing, yet end members are observed in nature for both cases. Lava lakes or Strombolian-style volcanoes are typical examples of open systems. Many very explosive eruptions show a phase of closed-system degassing with low levels of degassing prior to eruption ${ }^{169}$. It is very common for volcanoes to transition from open to closed through time, and even within a single eruptive phase, via a wide range of processes ${ }^{154,179-183}$. It is key to note that our definition of open and closed systems relates to shallow volatile-controlling conditions and differ from many petrological studies which refer to the connection between deep magma sources and shallow systems.

The third volcanic parameter considered is the presence of an active hydrothermal system. Arguably every volcano features a hydrothermal system; however, we define distinct end members of how well developed the hydrothermal system is. Some volcanoes display clear, persistent hydrothermal surface activity-e.g. acidic crater lakes, and fumaroles-whereas others show barely any visual sign of activity. For instance, it is quite common for smaller hydrothermal systems to dry due to proximity with magmatic bodies ${ }^{169}$. Thus, for the purpose of this classification, we will consider that a developed hydrothermal system is either present or absent.

We have chosen three parameters, each with two end-member cases, thus yielding $2^{3}=8$ possible combinations. Each combination corresponds to a type of volcano that will be susceptible to different triggering mechanisms. For the purpose of brevity, we limit the analysis to the five most common types, shown in Table 1. For each type, we provide a natural example and a list of the most efficient triggering mechanisms (Table 1). Importantly, volcanoes are not fixed in a given type but rather move between different categories with time, for example bimodal volcanoes can erupt two different viscosity magmas (e.g. Yellowstone, USA ${ }^{184}$ ). Timescales for these changes span orders of magnitudes from minutes (e.g. bubble nucleation) to millennia (e.g. fractional crystallization).

\section{Earthquakes}

The characteristics of the stress perturbation also play a major role in determining whether a given mechanism will trigger activity $^{6}$. These characteristics will result from a combination of (a) the earthquake's attributes and (b) the volcano's location with respect to the epicentre. Each earthquake features a unique set of characteristics (e.g. magnitude, focal mechanism, depth), and its 
Table 2 Possible eruption-triggering mechanisms for each of the five volcano types and different earthquake scenarios.

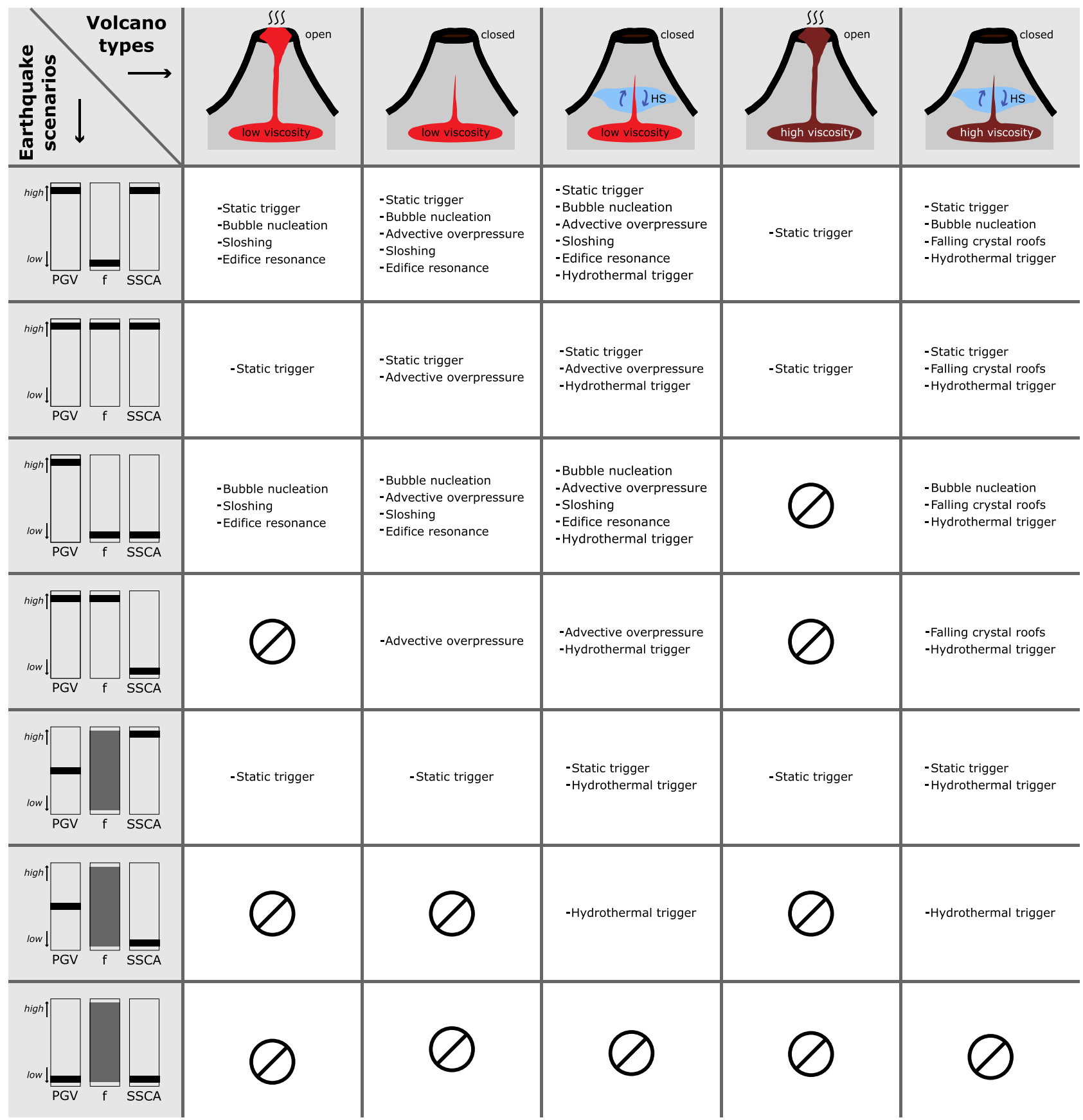

The three parameters for each earthquake scenario are represented by bar diagrams. A black bar indicates whether the parameter is high (top), moderate (middle) or low (bottom), whereas a grey area signifies that the parameter can take any value. "PGV", "f" and "SSCA", respectively, stand for "peak ground velocity", "frequency" and "static stress change amplitude". The symbols used for volcano types are identical to Table 1.

effects can be dramatically different from one location to another ${ }^{185}$. This will depend mainly on distance to the epicentre but also direction and local site amplification factors ${ }^{186,187}$. Moreover, some physical mechanisms are sensitive to the frequency of incoming seismic waves ${ }^{115,119}$. Hence, our choice of parameters should reflect this complexity whilst being simple enough for our classification to be effective. As for section "Volcano types", we have chosen three keys: (1) peak ground velocity, (2) frequency and (3) static stress change amplitude. We consider two possible end-member values for each one, yielding $2^{3}=8$ different scenarios.
The first parameter is peak ground velocity (PGV), referring to the largest shaking speed effectively felt at the magma reservoir location. This value will generally depend on a number of variables such as earthquake magnitude, distance and direction to the hypocentre, or country rock structure. For example, higher magnitudes and shorter distances will generally yield stronger PGVs (and vice versa). The distribution of PGVs can be directional, with stronger PGVs in the rupture direction ${ }^{147,185}$. There may also be an increase in PGV at certain great distances from the epicentre due to SmS arrivals ${ }^{186,188-190}$. Similarly, seismic waves may be focused by local crustal heterogeneities or amplified 
by topographic irregularities, thus resulting in significantly higher local PGVs $42,187,191-194$. We focus on two possible cases: strong and moderate PGVs. We adopt the criterion that strong PGVs may produce a magmatic response, whereas moderate PGVs only affect hydrothermal systems ${ }^{15,132}$ (and implicitly assume that there may exist very weak PGVs that do not trigger any response). This choice is motivated by field observations that hydrothermal systems are triggered by much smaller dynamic stresses than magmatic systems $6,15,51,59,60,195$.

The second parameter is frequency (or alternatively waveperiod). Most processes are greatly enhanced when the driving frequency approaches the system's resonance frequency. The resonance frequency of a magmatic reservoir depends on its size, geometry and the acoustic property of fluid ${ }^{196}$. It is generally in the range $0.001-1 \mathrm{~Hz}^{115,119,196}$. On the other hand, hydrothermal systems have higher resonance frequencies-typically $0.5-5$ $\mathrm{Hz}^{196,197}$. Most local earthquakes exhibit frequencies related to the propagation of surface wave components in the range 1-10 $\mathrm{Hz}$, but only very large earthquakes display frequencies components below $1 \mathrm{~Hz}$. Frequency is particularly relevant for melt and volatiles processes. For instance, sloshing and edifice resonance have been shown to occur only at very low frequencies ${ }^{115,119}$. Regarding bubble nucleation and growth processes, experimental results on magma are unavailable, but analogy with other low viscosity fluids suggests that frequency plays a capital role ${ }^{94}$. Regarding permeability changes in hydrothermal systems, frequency of incoming waves is also a crucial parameter, regardless of the mechanism considered $59,159,198$. Hence, we consider two limiting cases, low and high frequencies, with the low-frequency condition being matched when frequencies lower than $1 \mathrm{~Hz}$ are present. These frequency choices encompass two important frequency ranges for seismicity at volcanic systems; so called longperiod (LP) earthquakes and tremor (at 2-5 Hz) and very-long period (VLP) seismicity (at $0.1-0.03 \mathrm{~Hz}$ ) and hence relate to the periods of natural excitation and resonance in the volcanic edifice.

The third parameter is static stress change amplitude. Static stress changes are highly directional, i.e. the type and magnitude of the change will strongly depend on the azimuth with respect to the epicentre. Static stress changes at and around a volcano can be numerically computed ${ }^{199}$, and such approaches have been successfully applied to a multitude of volcanic complexes such as Mt. Fuji ${ }^{72}$, Kilauea 200 , Mauna Loa $^{69}$, Pinatubo ${ }^{83}$, Karymsky ${ }^{70}$, Cerro Negro $^{29,68}$, Sierra Negra ${ }^{75}$, Copahue ${ }^{73}$, Vesuvius ${ }^{67}$, Mt. Etna ${ }^{34,201}$, Merapi $^{202}$, Sinabung ${ }^{203}, \mathrm{Mt} \mathrm{Aso}^{74}$ and Stromboli ${ }^{34}$. We follow the generally accepted view that large static stress changes, both extensional and compressional, have the potential to trigger significant volcanic responses, whereas small stresses will be mostly negligible and leave the system unchanged. It is common to use $10 \mathrm{kPa}$ as a limit under which static stresses can be considered negligible, since this is approximately the magnitude of ocean tidal stresses ${ }^{6}$. For our classification, we restrict our attention to two end-member cases, namely large $(>10 \mathrm{kPa})$ and low $(<10 \mathrm{kPa})$ amplitudes.

\section{Discussion}

A new framework to examine seismic triggering of volcanoes. We have identified five common volcanic types as well as eight different seismic scenarios, yielding a total of $5 \times 8=40$ possible combinations. For each of these 40 cases, we examine the viable seismic-triggering mechanisms with the given conditions. The results are presented in Table 2, which then constitutes a firstorder classification of volcanoes, based on physical mechanisms with the potential for seismic-triggering.

Each column in Table 2 represents one of the five different volcano types defined in section "Volcano types", each featuring a different set of our three volcanic parameters. Each line in Table 2 represents a different earthquake scenario, based on the three seismic parameters discussed in section "Earthquakes". Each cell from Table 2 therefore illustrates a unique combination of an earthquake scenario with a specific volcano type, and lists the relevant mechanisms. This does not indicate that these mechanisms will necessarily happen in the case of a corresponding earthquake, but is rather an indication of which mechanisms are physically realistic with the given set of parameters. By extension, absent mechanisms are unlikely to trigger eruptions.

The first key outcome from Table 2 is that there is no empty column, meaning that all the volcano types presented may be seismically triggered. This result matches previous historical observations $^{8,10,16,33,56}$ that seismic triggering can happen for any type of volcano, in any tectonic setting. Furthermore, recent observations suggest that fluid movements dominate the response in the case of low-viscosity systems, whereas for more viscous systems, elastic processes may play a more important role 17,204 . This discrepancy is also captured in Table 2: the low-viscosity columns feature many more mechanisms associated with fluid movements (e.g., sloshing, advective overpressure, shaking-induced migration) than the high-viscosity cases.

Table 2 also reinforces the role of hydrothermal systems. Many studies highlight that hydrothermal areas are particularly sensitive to seismic perturbations ${ }^{6,42,48,52,53,128,156,170}$. Hydrothermal systems sit at a strategic location and constitute a key link between magmatic reservoirs and their environments. As such, it is important to carefully examine their role in eruption triggering ${ }^{4,138}$, and in particular, as intermediate between tectonic earthquakes and volcanic eruptions.

The second key observation from Table 2 is the disparity in the numbers of mechanisms, with values ranging between zero and six. It is tempting to directly relate the number of mechanisms in a cell to the likelihood of a seismically triggered eruption to occur, but this would most likely be erroneous. Table 2 does not include any quality assessment, i.e. it does not mention how efficient and how well understood is each mechanism. Some mechanisms are supported by an extensive range of theoretical and experimental data (e.g. static triggers, permeability changes in hydrothermal systems). Others rely on analogy or idealized assumptions (e.g. advective overpressure, bubble nucleation, falling crystal roofs). Section "Triggering mechanisms" provides some information on what supporting data are available for each mechanism and more quantitative considerations can be found in previous reviews $4,6,59$. A future improvement of this work could be to define and compute an effectiveness parameter for each mechanism. Another interesting future step would be to consider whether different mechanisms may occur simultaneously, interact and possibly compound their effects ${ }^{64}$.

It is a delicate task to assess whether a given eruption was seismically triggered ${ }^{6,24}$, but it is even more challenging to identify the responsible mechanism(s). The three volcanic parameters presented here can be assessed for most eruptions, thus constraining the possible mechanisms. These mechanisms may then be tested for validity. For instance, static stress changes can be computed numerically $35,69,72,73$, occurrence of resonant oscillations can be measured, crystal and bubble textures may retain a signature of nucleation events, and hydrothermal processes can be constrained with seismic monitoring ${ }^{205}$ and electromagnetic surveys ${ }^{206}$. Constraining the triggering mechanisms for a given type of volcano will be useful for future statistical studies, but may also inform and guide monitoring strategies and hazard assessment. 
The importance of critical state. A significant number of cells in Table 2 are empty (six, excluding the last line). This corroborates observations that seismically triggered eruptions are a rare occurrence $^{7}$. One of the reasons why earthquakes do not trigger more volcanic eruptions, and why some very large earthquakes trigger very little activity (e.g. Sumatra M9.2 2004 earthquake ${ }^{6}$ ), is that the range of conditions where seismic triggering is possible forms a very narrow window that is not often met $^{7,35}$. In particular, many studies have highlighted the need for a volcano to already be in a critical state in order to be seismically triggered $4,6,7,10,13,19,25,27,32,33,48,56,57,137,207$. Conceptually, a volcano may be considered in a critical state if it is close to erupting. This concept is particularly difficult to quantify, since criticality may take different forms at different volcanoes. For instance, Manga and Brodsky ${ }^{6}$ compare the overpressure in the magma chamber to the necessary tensile stress to initiate and sustain dyking to broadly estimate the degree of criticality. Bebbington and Marzocchi ${ }^{7}$ propose a "clock advance" mechanism, similar to what is found in the triggered-seismicity literature ${ }^{208}$. In this view, earthquakes merely accelerate the countdown to the next, inevitable eruption. Seismically triggered eruptions are then a consequence of a volcano being particularly advanced in its cycle towards eruption. For instance, the 1996 simultaneous eruptions of Karymsky Volcano and Akademia Nauk volcano occurred 2 days after an $\mathrm{M}_{\mathrm{w}} 7.1$ earthquake, but also marked the end of 14 years of continuous inflation ${ }^{70}$. This concept also offers an explanation to why the M9.2 Sumatra 2004 earthquake did not seem to trigger any eruption, despite being located in one of the most active volcanic zones in the world ${ }^{6,33}$. It is possible that none of the nearby volcanoes were close to erupting at the time. Although rarely reported, it appears that volcanoes that are not in a critical state can still be seismically triggered into eruption. For example, La Femina et al. ${ }^{29}$ describe the deposit of an eruption that would have seemingly not been possible to erupt without an earthquake. It is a formidable task to provide a universal definition of critical state, and something to consider for government agencies when assigning alert levels 209 as it is important for seismic triggering. At the very least, the presence of magma within reasonable distance to the surface appears to be a necessary condition, without which the cases presented in Table 2 are less relevant.

The discussion above highlights the difficulty to define what constitutes a seismically triggered eruption. An eruption is the culmination of a cascade of intertwined processes (magma generation, transport, storage, pressurization, fragmentation, etc...), and a single tectonic event cannot be held responsible for this entire chain. Earthquakes may have a less direct influence, and impact many of the different steps towards eruption (e.g. magma generation or melt segregation). For instance, seismic waves may play a key role in unlocking mushes ${ }^{210-213}$ or promoting diapirs via instabilities $^{214}$. These processes will in turn exert some control of the timing and style of eruption, but here we consider that such mechanisms do not trigger eruptions stricto sensu and thus lie beyond the scope of this study. We do nonetheless acknowledge their important role. Similarly, we mentioned the case of external triggers in section "External triggers"-sequences of events where an earthquake triggers a non-volcanic phenomenon which itself causes an eruption, and why we do not take them into account in our classification. Furthermore, for both the 1707 Fuji and 1991 Pinatubo eruptions, it was suggested that the static stress perturbation from an earthquake allowed basaltic magma to intrude into a dacitic reservoir, leading to magma mixing and eventually a Plinian eruption ${ }^{72,83}$. The static stress mechanism does fit within our classification, but it did not trigger the eruption per se. An elegant solution proposed by Marzocchi ${ }^{57}$ is to use the term "promote" rather than "trigger" in order to emphasize the complex nature of these processes.
Changes in unrest vs. eruption. A key observation from natural events is that earthquakes trigger a change in unrest more often than a magmatic eruption $17,22,27,28,42,215,216$. Here, we adopt the general view that unrest refers to any deviation from baseline behaviour and can take various geophysical or geochemical forms ${ }^{168,217,218}$. In the special case of seismically triggered unrest, volcanic seismicity is, by far, the most commonly reported phenomenon $42,45,62,122,132,219,220$. Other reported processes may include increased degassing 17,47 , changes in fumarolic activity $^{45,48}$, thermal activity ${ }^{26-28}$ or gas chemistry ${ }^{46}$. Reports and information about unrest are not as well reported as eruption data, due to the subjective definition of "baseline behaviour" or the lesser impact unrest may cause to surrounding communities $^{218}$. Yet, unrest episodes are generally directly identified as being related to the earthquakes (most often on the basis of spatio-temporal coincidence with the passage of seismic waves), whereas eruptions generally receive more careful statistical and physical analyses before a correlation is established ${ }^{24}$. Seismically triggered unrest is thus quite commonly accepted whereas seismically triggered eruptions retain some controversy.

For our purposes, a decisive question is whether the mechanisms responsible for triggered-unrest differ from the ones discussed previously. Many reports highlight that the onset of unrest seems to match seismic waves arrival, suggesting a dynamic origin $^{22,47,48,52,132,202}$. For instance, triggered seismicity is likely caused by small changes in permeability in hydrothermal systems, allowing geothermal fluids to migrate and change the local stress state 90 . Therefore, unrest may be triggered without the magmatic system being in a critical state, hence explaining the more frequent occurrence of triggered-unrest compared to triggered-eruptions.

Future directions. Our framework highlights that hydrothermal systems may be more sensitive than magma to changes induced by seismic activity. This could lead to heightened unrest in the hydrothermal system and to eruption if the magmatic system is in a critical state. The link between hydrothermal systems and magmatic systems is a key area for future research, with a particular focus on the role of fracture formation, fluid migration and wave propagation through the hydrothermal and magmatic systems and in particular the magma-hydrothermal transition zone. Increasing awareness about the interplay between the hydrothermal and magmatic systems might improve volcano monitoring outcomes in the aftermath of large earthquakes.

Monitoring approaches might more specifically address changes at hydrothermal systems and magmatic systems. Ground displacement studies and volcano geodesy, seismicity and tomography, geochemistry and petrology will soon have resolutions high enough to spatially and temporally distinguish the triggered effects at hydrothermal and magmatic systems. Regarding the mechanisms with the magma, current advances in high-temperature experimental facilities now allow for tests to be run at natural conditions. We suggest that this is an important step towards refining our understanding of the processes at stake here. In combination with further and more detailed analysis of ground monitoring and satellite data, the different volcano and hydrothermal effects might become distinguished following different types of earthquakes. Finally, as our records of earthquakes and heightened volcano unrest expands, it remains necessary to regularly update statistical and modelling analyses.

\section{Data availability}

The authors declare that the data supporting the findings of this study are available within the paper. 
Received: 13 July 2020; Accepted: 13 January 2021;

Published online: 12 February 2021

\section{References}

1. Nunn, P. D. Lashed by sharks, pelted by demons, drowned for apostasy: the value of myths that explain geohazards in the Asia-Pacific region. Asian Geogr. 31, 59-82 (2014).

2. Troll, V. R. et al. Ancient oral tradition describes volcano-earthquake interaction at merapi volcano, indonesia. Geogr. Ann. Ser. A Phys. Geogr. 97, 137-166 (2015).

3. Taggart, D. All the mountains shake, seismic and volcanic imagery in the Old Norse Literature of Pórr. Scr. Islandica Isl.ändska Sällskapets Årsb. 68, 99-122 (2017).

4. Hill, D. P., Pollitz, F. F. \& Newhall, C. G. Earthquake-volcano interactions. Phys. Today 55, 41-47 (2002).

5. Linde, A. T. \& Sacks, I. S. Triggering of volcanic eruptions. Nature 395, 888-890 (1998).

6. Manga, M. \& Brodsky, E. Seismic triggering of eruptions in the far field: volcanoes and geysers. Annu. Rev. Earth Planet. Sci. 34, 263-291 (2006).

7. Bebbington, M. S. \& Marzocchi, W. Stochastic models for earthquake triggering of volcanic eruptions. J. Geophys. Res. 116, B05204 (2011).

8. Sawi, T. M. \& Manga, M. Revisiting short-term earthquake triggered volcanism. Bull. Volcanol. 80, 57 (2018).

9. Koyama, M. Mechanical coupling between volcanic unrests and large earthquakes: a review of examples and mechanisms. J. Geogr. 111, 222-232 (2002).

10. Eggert, S. \& Walter, T. R. Volcanic activity before and after large tectonic earthquakes: observations and statistical significance. Tectonophysics $\mathbf{4 7 1}$, 14-26 (2009).

11. Watt, S. F. L., Pyle, D. M. \& Mather, T. A. The influence of great earthquakes on volcanic eruption rate along the Chilean subduction zone. Earth Planet. Sci. Lett. 277, 399-407 (2009).

12. Latter, J. H. The interdependence of seismic and volcanic phenomena: some space - Time relationships in seismicity and volcanism. Bull. Volcanol. 35, 127-142 (1971).

13. Yamashina, K. \& Nakamura, K. Correlations between tectonic earthquakes and volcanic activity of Izu-Oshima Volcano, Japan. J. Volcanol. Geotherm. Res. 4, 233-250 (1978).

14. Ebmeier, S. K. et al. Shallow earthquake inhibits unrest near Chiles-Cerro Negro volcanoes, Ecuador-Colombian border. Earth Planet. Sci. Lett. 450, 283-291 (2016).

15. Farías, C. \& Basualto, D. Reactivating and calming volcanoes: the 2015 MW 8.3 Illapel megathrust strike. Geophys. Res. Lett. 47, 1-10 (2020).

16. Bonali, F. L., Tibaldi, A., Corazzato, C., Tormey, D. R. \& Lara, L. E. Quantifying the effect of large earthquakes in promoting eruptions due to stress changes on magma pathway: the Chile case. Tectonophysics 583, 54-67 (2013).

17. Avouris, D. M., Carn, S. A. \& Waite, G. P. Triggering of volcanic degassing by large earthquakes. Geology 45, G39074.1 (2017).

18. MacGregor, A. G. Prediction in relation to seismo-volcanic phenomena in the caribbean volcanic arc. Bull. Volcanol. 8, 69-86 (1949).

19. Yokoyama, I. Volcanic eruptions triggered by tectonic earthquakes. Geophys. Bull. Hokkaido Univ. 25, 129-139 (1971)

20. Tilling, R. I. et al. Earthquakes and related catastrophic events, Island of Hawaii, November 29, 1975; A preliminary report. Geol. Surv. https://doi.org/ 10.3133/cir740 (1976).

21. Barquero, R., Lesage, P., Metaxian, J. P., Creusot, A. \& Fernández, M. La crisis sismica en el Volcán Irazú en 1991 (Costa Rica). Rev. Geol. Amer. Central 18, 5-18 (1995).

22. Carbone, D., Jousset, P. \& Musumeci, C. Gravity "steps" at Mt. Etna volcano (Italy): Instrumental effects or evidences of earthquake-triggered magma density changes? Geophys. Res. Lett. 36, (2009).

23. Cannata, A. et al. Response of Mount Etna to dynamic stresses from distant earthquakes. J. Geophys. Res. Solid Earth 115, 1-18 (2010).

24. Yamazaki, K., Teraishi, M., Komatsu, S., Sonoda, Y. \& Kano, Y. On the possibility of the 2011 Tohoku-oki earthquake reactivating Shinmoe-dake volcano, southwest Japan: Insights from strain data measured in vaults. Nat. Hazards Earth Syst. Sci. 11, 2655-2661 (2011).

25. Mora-Stock, C. et al. Comparison of seismic activity for Llaima and Villarrica volcanoes prior to and after the Maule 2010 earthquake. Int. J. Earth Sci. 103, 2015-2028 (2014).

26. Harris, A. J. L. \& Ripepe, M. Regional earthquake as a trigger for enhanced volcanic activity: evidence from MODIS thermal data. Geophys. Res. Lett. 34, 1-6 (2007).

27. Delle Donne, D., Harris, A. J. L., Ripepe, M. \& Wright, R. Earthquake-induced thermal anomalies at active volcanoes. Geology 38, 771-774 (2010)
28. Hill-Butler, C., Blackett, M., Wright, R. \& Trodd, N. The co-incidence of earthquakes and volcanoes: assessing global volcanic radiant flux responses to earthquakes in the 21st century. J. Volcanol. Geotherm. Res. 393, 106770 (2020).

29. La Femina, P. C., Connor, C. B., Hill, B. E., Strauch, W. \& Saballos, J. A. Magma-tectonic interactions in Nicaragua: the 1999 seismic swarm and eruption of Cerro Negro volcano. J. Volcanol. Geotherm. Res. 137, 187-199 (2004)

30. Higgins, M. D. The Cascadia megathrust earthquake of 1700 may have rejuvenated an isolated basalt volcano in western Canada: age and petrographic evidence. J. Volcanol. Geotherm. Res. 179, 149-156 (2009).

31. Allan, A. S. R., Wilson, C. J. N., Millet, M. A. \& Wysoczanski, R. J. The invisible hand: tectonic triggering and modulation of a rhyolitic supereruption. Geology 40, 563-566 (2012).

32. Barrientos, S. E. Large thrust earthquakes and volcanic eruptions. Pure Appl. Geophys. 142, 225-237 (1994).

33. Walter, T. R. \& Amelung, F. Volcanic eruptions following $M \geq 9$ megathrust earthquakes: implications for the Sumatra-Andaman volcanoes. Geology 35, 539-542 (2007).

34. Walter, T. R. et al. Simultaneous magma and gas eruptions at three volcanoes in southern Italy: an earthquake trigger? Geology 37, 251-254 (2009).

35. Hamling, I. J. \& Kilgour, G. Goldilocks conditions required for earthquakes to trigger basaltic eruptions: Evidence from the 2015 Ambrym eruption. Sci. Adv. 6, eaaz5261 (2020).

36. Carniel, R., Di Cecca, M. \& Rouland, D. Ambrym, Vanuatu (July-August 2000): spectral and dynamical transitions on the hours-to-days timescale. $J$. Volcanol. Geotherm. Res. 128, 1-13 (2003).

37. Ortiz, R. et al. Villarrica volcano (Chile): characteristics of the volcanic tremor and forecasting of small explosions by means of a material failure method. $J$. Volcanol. Geotherm. Res. 128, 247-259 (2003).

38. Tárraga, M. et al. Dynamical parameter analysis of continuous seismic signals of Popocatépetl volcano (Central Mexico): a case of tectonic earthquakes influencing volcanic activity. Acta Geophys. 60, 664-681 (2012).

39. Jousset, P. et al. Signs of magma ascent in LP and VLP seismic events and link to degassing: an example from the 2010 explosive eruption at Merapi volcano, Indonesia. J. Volcanol. Geotherm. Res. 261, 171-192 (2013).

40. Carr, B. B., Clarke, A. B. \& de' Michieli Vitturi, M. Earthquake induced variations in extrusion rate: a numerical modeling approach to the 2006 eruption of Merapi Volcano (Indonesia). Earth Planet. Sci. Lett. 482, 377-387 (2018).

41. Prejean, S. G. et al. Remotely triggered seismicity on the United States West Coast following the Mw 7.9 Denali fault earthquake. Bull. Seismol. Soc. Am. 94, S348-S359 (2004)

42. Moran, S. C., Power, J. A., Stihler, S. D., Sánchez, J. J. \& Caplan-Auerbach, J. Earthquake triggering at Alaskan volcanoes following the 3 November 2002 Denali fault earthquake. Bull. Seismol. Soc. Am. 94, S300-S309 (2004).

43. Yukutake, Y. et al. Remotely-triggered seismicity in the Hakone volcano following the 2011 off the Pacific coast of Tohoku Earthquake. Earth Planets Space 63, 737-740 (2011).

44. Farías, C., Lupi, M., Fuchs, F. \& Miller, S. A. Seismic activity of the Nevados de Chillán volcanic complex after the 2010 Mw8.8 Maule, Chile, earthquake. J. Volcanol. Geotherm. Res. 283, 116-126 (2014).

45. Lin, C. H. Dynamic triggering of volcano drumbeat-like seismicity at the Tatun volcano group in Taiwan. Geophys. J. Int. 210, 354-359 (2017).

46. Cigolini, C., Laiolo, M. \& Coppola, D. Earthquake - volcano interactions detected from radon degassing at Stromboli (Italy). Earth Planet. Sci. Lett. 257, 511-525 (2007).

47. Gresse, M., Vandemeulebrouck, J., Byrdina, S., Chiodini, G. \& Bruno, P. P. Changes in $\mathrm{CO}_{2}$ diffuse degassing induced by the passing of seismic waves. J. Volcanol. Geotherm. Res. 320, 12-18 (2016).

48. Madonia, P., Cusano, P., Diliberto, I. S. \& Cangemi, M. Thermal anomalies in fumaroles at Vulcano island (Italy) and their relationship with seismic activity. Phys. Chem. Earth A/B/C 63, 160-169 (2013).

49. Takada, Y. \& Fukushima, Y. Volcanic subsidence triggered by the 2011 Tohoku earthquake in Japan. Nat. Geosci. 6, 637-641 (2013).

50. Pritchard, M. E., Jay, J. A., Aron, F., Henderson, S. T. \& Lara, L. E. Subsidence at southern Andes volcanoes induced by the 2010 Maule, Chile earthquake. Nat. Geosci. 6, 632-636 (2013).

51. Marler, G. D. \& White, D. E. Seismic geyser and its bearing on the origin and evolution of geysers and hot springs of Yellowstone National Park. Geol. Soc. Am. Bull. 86, 749 (1975).

52. Hill, D. P. et al. Seismicity remotely triggered by the magnitude 7.3 Landers, California, Earthquake. Science 260, 1617-1623 (1993).

53. Husen, S., Taylor, R., Smith, R. B. \& Healser, H. Changes in geyser eruption behavior and remotely triggered seismicity in Yellowstone National Park produced by the 2002 M 7.9 Denali fault earthquake, Alaska. Geology 32, 537 (2004)

54. Rouwet, D., Mora-Amador, R., Ramírez-Umaña, C. J., González, G. \& Inguaggiato, S. Dynamic fluid recycling at Laguna Caliente (Poás, Costa Rica) 
before and during the 2006 - ongoing phreatic eruption cycle (2005-10). In Geochemistry and Geophysics of Active Volcanic Lakes (eds Ohba, T., Capaccioni, B. \& Caudron, C.) (The Geological Society of London, 2016).

55. Hurwitz, S. \& Manga, M. The fascinating and complex dynamics of geyser eruptions. Annu. Rev. Earth Planet. Sci. 45, 31-59 (2017).

56. Nishimura, T. Triggering of volcanic eruptions by large earthquakes. Geophys. Res. Lett. 44, 7750-7756 (2017).

57. Marzocchi, W. Remote seismic influence on large explosive eruptions. J. Geophys. Res. 107, EPM 6-1-EPM 6-7 (2002).

58. Alam, M. \& Kimura, M. Statistical analysis of time-distance relationship between volcanic eruptions and great earthquakes in Japan. Earth Planets Space 56, 179-192 (2004).

59. Manga, M. et al. Changes in permeability caused by transient stresses: field observations, experiments, and mechanisms. Rev. Geophys. 50, (2012).

60. Mazzini, A. \& Etiope, G. Mud volcanism: an updated review. Earth-Sci. Rev. 168, 81-112 (2017).

61. Marzocchi, W., Casarotti, E. \& Piersanti, A. Modeling the stress variations induced by great earthquakes on the largest volcanic eruptions of the 20th century. J. Geophys. Res. Solid Earth 107, ESE 13-1-ESE 13-8 (2002).

62. West, M., Sánchez, J. J. \& McNutt, S. R. Periodically triggered seismicity at Mount Wrangell, Alaska, after the Sumatra Earthquake. Science 308, 1144-1146 (2005).

63. Wang, C.-Y. \& Manga, M. Hydrologic responses to earthquakes and a general metric. Geofluids 10, 206-216 (2010).

64. Sulpizio, R. \& Massaro, S. Influence of stress field changes on eruption initiation and dynamics: a review. Front. Earth Sci. 5, 1-11 (2017).

65. Steacy, S., Gomberg, J. \& Cocco, M. Introduction to special section: stress transfer, earthquake triggering, and time-dependent seismic hazard. $J$. Geophys. Res. Solid Earth 110, 1-12 (2005).

66. Nakamura, K. Volcano structure and possible mechanical correlation between volcanic eruptions and earthquakes. Bull. Volcanol. Soc. Jpn. Second Ser. 20, 229-240 (1975).

67. Nostro, C., Stein, R. S., Cocco, M., Belardinelli, M. E. \& Marzocchi, W. Twoway coupling between Vesuvius eruptions and southern Apennine earthquakes, Italy, by elastic stress transfer. J. Geophys. Res. Solid Earth 103, 24487-24504 (1998).

68. Díez, M., La Femina, P. C., Connor, C. B., Strauch, W. \& Tenorio, V. Evidence for static stress changes triggering the 1999 eruption of Cerro Negro Volcano, Nicaragua and regional aftershock sequences. Geophys. Res. Lett. 32, 1-4 (2005).

69. Walter, T. R. \& Amelung, F. Volcano-earthquake interaction at Mauna Loa volcano, Hawaii. J. Geophys. Res. 111, B05204 (2006).

70. Walter, T. R. How a tectonic earthquake may wake up volcanoes: Stress transfer during the 1996 earthquake-eruption sequence at the Karymsky Volcanic Group, Kamchatka. Earth Planet. Sci. Lett. 264, 347-359 (2007).

71. Wang, F., Kang, S. Z., Zhao, W. Y. \& Min, W. Influence of the March 11, 2011 Mw 9.0 Tohoku-oki earthquake on regional volcanic activities. Chin. Sci. Bull. 56, 2077-2081 (2011).

72. Chesley, C., La Femina, P. C., Puskas, C. \& Kobayashi, D. The 1707 M w 8.7 Hoei earthquake triggered the largest historical eruption of Mt. Fuji. Geophys. Res. Lett. 39, 2012GL053868 (2012).

73. Bonali, F. L. Earthquake-induced static stress change on magma pathway in promoting the 2012 Copahue eruption. Tectonophysics 608, 127-137 (2013).

74. Ozawa, T., Fujita, E. \& Ueda, H. Crustal deformation associated with the 2016 Kumamoto Earthquake and its effect on the magma system of Aso volcano. Earth, Planets Space 68 (2016).

75. Gregg, P. M. et al. Stress triggering of the 2005 eruption of Sierra Negra Volcano, Galápagos. Geophys. Res. Lett. 45, 288-13,297 (2018).

76. Shimomura, Y., Nishimura, T. \& Sato, H. Bubble growth processes in magma surrounded by an elastic medium. J. Volcanol. Geotherm. Res. 155, 307-322 (2006).

77. Ichihara, M. \& Nishimura, T. Pressure impulses generated by bubbles interacting with ambient perturbation. In Extreme Environmental Events: Complexity in Forecasting and Early Warning (ed. Meyers, R. A.) 731-752 (Springer, 2009).

78. Lupi, M. \& Miller, S. A. Short-lived tectonic switch mechanism for long-term pulses of volcanic activity after mega-thrust earthquakes. Solid Earth 5, 13-24 (2014).

79. Pérez-Flores, P. et al. The effect of offset on fracture permeability of rocks from the Southern Andes Volcanic Zone, Chile. J. Struct. Geol. 104, 142-158 (2017).

80. Kimura, M. Significant eruptive activities related to large interplate earthquakes in the northwestern Pacific margin. J. Phys. Earth 26, S557-S570 (1978).

81. McNutt, S. R. \& Beavan, R. J. Eruptions of Pavlof Volcano and their possible modulation by ocean load and tectonic stresses. J. Geophys. Res. Solid Earth 92, 11509-11523 (1987).

82. Kimura, M. Relationship between volcanic eruption and large earthquakes in the vicinity of Japan. Annu. Rev. Fluid Mech. 37, 293-317 (1994).
83. Bautista, B. C. et al. Relationship of regional and local structures to Mount Pinatubo activity. In Fire and Mud: Eruptions and Lahars of Mount Pinatubo, Philippines (eds Newhall, C. G. \& Punongbayan, R. S.) 351-370 (Philippine Institute of Volcanology and Seismology, 1996).

84. Rikitake, T. \& Sato, R. Up-squeezing of magma under tectonic stress. J. Phys. Earth 37, 303-311 (1989).

85. Jónsson, S. Stress interaction between magma accumulation and trapdoor faulting on Sierra Negra volcano, Galápagos. Tectonophysics 471, 36-44 (2009).

86. Maccaferri, F., Rivalta, E., Passarelli, L. \& Aoki, Y. On the mechanisms governing dike arrest: Insight from the 2000 Miyakejima dike injection. Earth Planet. Sci. Lett. 434, 64-74 (2016).

87. Xu, W., Jónsson, S., Corbi, F. \& Rivalta, E. Graben formation and dike arrest during the 2009 Harrat Lunayyir dike intrusion in Saudi Arabia: insights from InSAR, stress calculations and analog experiments. J. Geophys. Res. Solid Earth 121, 2837-2851 (2016).

88. Nur, A. \& Mavko, G. Postseismic viscoelastic rebound. Science 183, 204-206 (1974).

89. Pollitz, F. F. Postseismic relaxation theory on the spherical Earth. Bull. Seismol. Soc. Am. 82, 422-453 (1992).

90. Hill, D. P. \& Prejean, S. G. Dynamic triggering. In Treatise on Geophysics (ed. Schubert, G.) 274-304 (Elsevier B.V., 2015).

91. Lay, T. \& Wallace, T. C. Modern Global Seismology (Academic Press, 1995).

92. Gomberg, J., Reasenberg, P. A., Bodin, P. \& Harris, R. A. Earthquake triggering by seismic waves following the landers and hector mine earthquakes. Nature 411, 462-466 (2001).

93. Young, F. R. Cavitation (Imperial College Press, 1989).

94. Crews, J. B. \& Cooper, C. A. Experimental evidence for seismically initiated gas bubble nucleation and growth in groundwater as a mechanism for coseismic borehole water level rise and remotely triggered seismicity. J. Geophys. Res. Solid Earth 119, 7079-7091 (2014).

95. Shea, T. Bubble nucleation in magmas: a dominantly heterogeneous process? J. Volcanol. Geotherm. Res. 343, 155-170 (2017).

96. Mangan, M. \& Sisson, T. Delayed, disequilibrium degassing in rhyolite magma: decompression experiments and implications for explosive volcanism. Earth Planet. Sci. Lett. 183, 441-455 (2000).

97. Hurwitz, S. \& Navon, O. Bubble nucleation in rhyolitic melts: Experiments at high pressure, temperature, and water content. Earth Planet. Sci. Lett. 122, 267-280 (1994).

98. Carey, R. J. et al. Externally triggered renewed bubble nucleation in basaltic magma: the 12 October 2008 eruption at Halema'uma'u Overlook vent, Killauea, Hawai'i, USA. J. Geophys. Res. Solid Earth 117 (2012).

99. Eller, A. I. \& Flynn, H. G. Rectified diffusion during nonlinear pulsations of cavitation bubbles. J. Acoust. Soc. Am. 37, 493-503 (1965).

100. Sturtevant, B., Kanamori, H. \& Brodsky, E. E. Seismic triggering by rectified diffusion in geothermal systems. J. Geophys. Res. Solid Earth 101, 25269-25282 (1996).

101. Brodsky, E. E., Sturtevant, B. \& Kanamori, H. Earthquakes, volcanoes, and rectified diffusion. J. Geophys. Res. Solid Earth 103, 23827-23838 (1998).

102. Ichihara, M. \& Brodsky, E. E. A limit on the effect of rectified diffusion in volcanic systems. Geophys. Res. Lett. 33, L02316 (2006).

103. Lautze, N. C., Sisson, T. W., Mangan, M. T. \& Grove, T. L. Segregating gas from melt: an experimental study of the Ostwald ripening of vapor bubbles in magmas. Contrib. Mineral. Petrol. 161, 331-347 (2011).

104. Masotta, M. \& Keppler, H. A new hydrothermal moissanite cell apparatus for optical in-situ observations at high pressure and high temperature, with applications to bubble nucleation in silicate melts. Am. Mineral. 102, 2022-2031 (2017).

105. Igualada-Villodre, E., Medina-Palomo, A., Vega-Martínez, P. \& RodríguezRodríguez, J. Transient effects in the translation of bubbles insonated with acoustic pulses of finite duration. J. Fluid Mech. 836, 649-693 (2018).

106. Sahagian, D. L. \& Proussevitch, A. A. Bubbles in volcanic systems. Nature 359, 485 (1992).

107. Linde, A. T., Sacks, I. S., Johnston, M. J. S., Hill, D. P. \& Bilham, R. G. Increased pressure from rising bubbles as a mechanism for remotely triggered seismicity. Nature 371, 408-410 (1994).

108. Czekaluk, E. B. Osnovy piezometrii zalegei nefti i gaza (in Russian). Gostechizdat (1961).

109. Steinberg, G. S., Steinberg, A. S. \& Merzhanov, A. G. Fluid mechanism of pressure growth in volcanic (magmatic) systems. Mod. Geol. 13, 257-265 (1989).

110. Bagdassarov, N. Pressure and volume changes in magmatic systems due to the vertical displacement of compressible materials. J. Volcanol. Geotherm. Res. 63, 95-100 (1994).

111. Pyle, D. M. \& Pyle, D. L. Bubble migration and the initiation of volcanic eruptions. J. Volcanol. Geotherm. Res. 67, 227-232 (1995).

112. Woith, H. et al. Heterogeneous response of hydrogeological systems to the Izmit and Düzce (Turkey) earthquakes of 1999. Hydrogeol. J. 11, 113-121 (2003). 
113. Iwata, S., Yamada, Y., Takashima, T. \& Mori, H. Pressure-oscillation defoaming for viscoelastic fluid. J. Nonnewton. Fluid Mech. 151, 30-37 (2008).

114. De Corato, M., Dimakopoulos, Y. \& Tsamopoulos, J. The rising velocity of a slowly pulsating bubble in a shear-thinning fluid. Phys. Fluids 31, 083103 (2019).

115. Namiki, A., Rivalta, E., Woith, H. \& Walter, T. R. Sloshing of a bubbly magma reservoir as a mechanism of triggered eruptions. J. Volcanol. Geotherm. Res. 320, 156-171 (2016).

116. Miles, J. W. On the sloshing of liquid in a cylindrical tank. Report from The Ramo-Wooldridge Corporation, Cruided Missile Research Division, Aeromechanics Section (1956).

117. Housner, G. W. Dynamic pressures on accelerated fluid containers. Bull. Seismol. Soc. Am. 47, 15-35 (1957).

118. Abramson, H. N. The Dynamic Behavior of Liquids in Moving Containers Vol. SP-106 (National Aeronautics and Space Administration, 1966).

119. Namiki, A. et al. Volcanic activities triggered or inhibited by resonance of volcanic edifices to large earthquakes. Geology 47, 67-70 (2018).

120. Browne, P. R. \& Lawless, J. Characteristics of hydrothermal eruptions, with examples from New Zealand and elsewhere. Earth-Sci. Rev. 52, 299-331 (2001).

121. Peng, Z., Hill, D. P., Shelly, D. R. \& Aiken, C. Remotely triggered microearthquakes and tremor in central California following the $2010 \mathrm{Mw} 8.8$ Chile earthquake. Geophys. Res. Lett. 37 (2010).

122. Jay, J. A. et al. Shallow seismicity, triggered seismicity, and ambient noise tomography at the long-dormant Uturuncu Volcano, Bolivia. Bull. Volcanol. 74, 817-837 (2012).

123. Surve, G. \& Mohan, G. Possible evidence of remotely triggered and delayed seismicity due to the 2001 Bhuj earthquake $(\mathrm{Mw}=7.6)$ in western India. Nat. Hazards 64, 299-310 (2012).

124. Drake, B. D. et al. Evolution of a dynamic paleo-hydrothermal system at Mangatete, Taupo Volcanic Zone, New Zealand. J. Volcanol. Geotherm. Res. 282, 19-35 (2014)

125. Kosuga, M. Seismic activity near the Moriyoshi-zan volcano in Akita Prefecture, northeastern Japan: Implications for geofluid migration and a midcrustal geofluid reservoir Geofluid processes in subduction zones and mantle dynamics. Earth Planets Space 66, 1-16 (2014).

126. Hurwitz, S., Sohn, R. A., Luttrell, K. \& Manga, M. Triggering and modulation of geyser eruptions in Yellowstone National Park by earthquakes, earth tides, and weather. J. Geophys. Res. Solid Earth 119, 1718-1737 (2014).

127. Lin, C. H. Probable dynamic triggering of phreatic eruption in the Tatun volcano group of Taiwan. J. Asian Earth Sci. 149, 78-85 (2017).

128. Girault, F. et al. Persistent $\mathrm{CO}_{2}$ emissions and hydrothermal unrest following the 2015 earthquake in Nepal. Nat. Commun. 9, 2956 (2018).

129. Peng, Z. et al. Remote triggering of microearthquakes and tremor in New Zealand following the 2016 Mw 7.8 Kaikoura earthquake. Bull. Seismol. Soc. Am. 108, 1784-1793 (2018).

130. Loame, R. C. et al. Using paleoseismology and tephrochronology to reconstruct fault rupturing and hydrothermal activity since c. 40 ka in Taupo Rift, New Zealand. Quat. Int. 500, 52-70 (2019).

131. Saade, M. et al. Evidence of reactivation of a hydrothermal system from seismic anisotropy changes. Nat. Commun. 10, 1-8 (2019).

132. Farías, C. \& Galván, B. Numerical wave propagation study of the unusual response of Nevados de Chillán volcano to two aftershocks of the $2010 \mathrm{MW}=$ 8.8 Maule earthquake. J. Volcanol. Geotherm. Res. 389, 106735 (2020).

133. Revil, A. et al. Hydrogeology of Stromboli volcano, Aeolian Islands (Italy) from the interpretation of resistivity tomograms, self-potential, soil temperature and soil $\mathrm{CO}_{2}$ concentration measurements. Geophys. J. Int. 186, 1078-1094 (2011).

134. Vargas, C. A. et al. Breathing of the Nevado del Ruiz volcano reservoir, Colombia, inferred from repeated seismic tomography. Sci. Rep. 7, 8-13 (2017).

135. Healy, J., Lloyd, E. F., Banwell, C. J. \& Adams, R. D. Volcanic eruption on Raoul Island, November 1964. Nature 205, 743-745 (1965).

136. Christenson, B. W. et al. Hazards from hydrothermally sealed volcanic conduits. EOS Trans. Am. Geophys. Union 88, 53-55 (2007).

137. Lupi, M. et al. Regional earthquakes followed by delayed ground uplifts at Campi Flegrei Caldera, Italy: Arguments for a causal link. Earth Planet. Sci. Lett. 474, 436-446 (2017).

138. Jolly, A. D. On the shallow volcanic response to remote seismicity. Geology 47, 95-96 (2019)

139. Elkhoury, J. E., Brodsky, E. E. \& Agnew, D. C. Seismic waves increase permeability. Nature 441, 1135-1138 (2006).

140. Wang, C. -Y. \& Manga, M. Earthquakes and Water Vol. 114 (Springer, 2009).

141. Rojstaczer, S., Wolf, S. \& Michel, R. Permeability enhancement in the shallow crust as a cause of earthquake-induced hydrological changes. Nature 373, 237-239 (1995).

142. Manga, M., Brodsky, E. E. \& Boone, M. Response of streamflow to multiple earthquakes. Geophys. Res. Lett. 30 (2003).
143. Rojstaczer, S. \& Wolf, S. Permeability changes associated with large earthquakes: an example from Loma Prieta, California. Geology 20, 211-214 (1992).

144. Roeloffs, E. A. Persistent water level changes in a well near Parkfield, California, due to local and distant earthquakes. J. Geophys. Res. Solid Earth 103, 869-889 (1998).

145. Kocharyan, G. G. et al. Hydrologic response of underground reservoirs to seismic vibrations. Izv. Phys. Solid Earth 47, 1071-1082 (2011).

146. Yan, R., Woith, H. \& Wang, R. Groundwater level changes induced by the 2011 Tohoku earthquake in China mainland. Geophys. J. Int. 199, 533-548 (2014).

147. Weaver, K. C. et al. Seismological and hydrogeological controls on New Zealand-wide groundwater level changes induced by the $2016 \mathrm{M}$ w 7.8 Kaikōura earthquake. Geofluids 2019, 1-18 (2019).

148. Mogi, K., Mochizuki, H. \& Kurokawa, Y. Temperature changes in an artesian spring at Usami in the Izu Peninsula (Japan) and their relation to earthquakes. Tectonophysics 159, 95-108 (1989).

149. Demezhko, D. Y., Yurkov, A. K., Outkin, V. I. \& Shchapov, V. A. Temperature changes in the KUN-1 borehole, Kunashir Island, induced by the Tohoku Earthquake (March 11, 2011, M = 9.0). Dokl. Earth Sci. 445, 883-887 (2012).

150. He, A. \& Singh, R. P. Coseismic groundwater temperature response associated with the Wenchuan earthquake. Pure Appl. Geophys. 177, 109-120 (2020).

151. Mellors, R., Kilb, D., Aliyev, A., Gasanov, A. \& Yetirmishli, G. Correlations between earthquakes and large mud volcano eruptions. J. Geophys. Res. Solid Earth 112 (2007).

152. Manga, M., Brumm, M. \& Rudolph, M. L. Earthquake triggering of mud volcanoes. Mar. Pet. Geol. 26, 1785-1798 (2009).

153. Bonini, M., Rudolph, M. L. \& Manga, M. Long- and short-term triggering and modulation of mud volcano eruptions by earthquakes. Tectonophysics 672-673, 190-211 (2016).

154. Christenson, B. W. et al. Cyclic processes and factors leading to phreatic eruption events: insights from the 25 September 2007 eruption through Ruapehu Crater Lake, New Zealand. J. Volcanol. Geotherm. Res. 191, 15-32 (2010).

155. Heap, M. J. et al. A multidisciplinary approach to quantify the permeability of the Whakaari/White Island volcanic hydrothermal system (Taupo Volcanic Zone, New Zealand). J. Volcanol. Geotherm. Res. 332, 88-108 (2017).

156. Brodsky, E. E., Roeloffs, E., Woodcock, D., Gall, I. \& Manga, M. A mechanism for sustained groundwater pressure changes induced by distant earthquakes. J. Geophys. Res. 108, 2390 (2003).

157. Candela, T., Brodsky, E. E., Marone, C. \& Elsworth, D. Laboratory evidence for particle mobilization as a mechanism for permeability enhancement via dynamic stressing. Earth Planet. Sci. Lett. 392, 279-291 (2014).

158. Candela, T., Brodsky, E. E., Marone, C. \& Elsworth, D. Flow rate dictates permeability enhancement during fluid pressure oscillations in laboratory experiments. J. Geophys. Res. Solid Earth 120, 2037-2055 (2015).

159. Barbosa, N. D., Hunziker, J., Lissa, S., Saenger, E. H. \& Lupi, M. Fracture unclogging: a numerical study of seismically induced viscous shear stresses in fluidsaturated fractured rocks. J. Geophys. Res. Solid Earth 124, 11705-11727 (2019).

160. Shi, Y., Liao, X., Zhang, D. \& Liu, C. Seismic waves could decrease the permeability of the shallow crust. Geophys. Res. Lett. 46, 6371-6377 (2019).

161. Faoro, I., Elsworth, D. \& Marone, C. Permeability evolution during dynamic stressing of dual permeability media. J. Geophys. Res. Solid Earth 117 (2012).

162. Wang, C.-Y., Liao, X., Wang, L.-P., Wang, C.-H. \& Manga, M. Large earthquakes create vertical permeability by breaching aquitards. Water Resour. Res. 52, 5923-5937 (2016).

163. Shokouhi, P. et al. Dynamic stressing of naturally fractured rocks: on the relation between transient changes in permeability and elastic wave velocity. Geophys. Res. Lett. 47, 1-10 (2020).

164. Fournier, R. O. Hydrothermal processes related to movement of fluid from plastic into brittle rock in the magmatic-epithermal environment. Econ. Geol. 94, 1193-1211 (1999)

165. Christiansen, R. L. \& Peterson, D. W. Chronology of the 1980 eruptive activity. In The 1980 Eruptions of Mount St. Helens, Washington Geological Survey Professional Paper 1250 (eds Lipman, P. W. \& Mullineaux, D. R.) 17-30 (USGS, 1981)

166. McGuire, W. J. Volcano instability: a review of contemporary themes. Geol. Soc. Spec. Publ. 110, 1-23 (1996).

167. Manconi, A., Longpe, M. A., Walter, T. R., Troll, V. R. \& Hansteen, T. H. The effects of flank collapses on volcano plumbing systems. Geology 37, 1099-1102 (2009).

168. Sandri, L., Acocella, V. \& Newhall, C. Searching for patterns in caldera unrest. Geochem. Geophys. Geosyst. 18, 2748-2768 (2017).

169. Stix, J. Understanding fast and slow unrest at volcanoes and implications for eruption forecasting. Front. Earth Sci. 6, 56 (2018).

170. Johnson, H. P. et al. Earthquake-induced changes in a hydrothermal system on the Juan de Fuca mid-ocean ridge. Nature 407, 174-177 (2000).

171. Dziak, R. P., Chadwick, W. W., Fox, C. G. \& Embley, R. W. Hydrothermal temperature changes at the southern Juan de Fuca Ridge associated with a $\mathrm{Mw}$ 6.2 Blanco Transform earthquake. Geology 31, 119-122 (2003). 
172. Špičák, A. \& Vaněk, J. Earthquake swarms reveal submarine magma unrest induced by distant mega-earthquakes: Andaman Sea region. J. Asian Earth Sci. 116, 155-163 (2016).

173. Vona, A., Romano, C., Dingwell, D. B. \& Giordano, D. The rheology of crystal-bearing basaltic magmas from Stromboli and Etna. Geochim. Cosmochim. Acta 75, 3214-3236 (2011).

174. Chevrel, M. O. et al. The viscosity of pāhoehoe lava: In situ syn-eruptive measurements from Kilauea, Hawaii. Earth Planet. Sci. Lett. 493, 161-171 (2018).

175. Shaw, H. R. Obsidian- $\mathrm{H}_{2} \mathrm{O}$ viscosities at 1000 and 2000 bars in the temperature range $700^{\circ}$ to $900^{\circ} \mathrm{C}$. J. Geophys. Res. 68, 6337-6343 (1963).

176. Lejeune, A.-M. \& Richet, P. Rheology of crystal-bearing silicate melts: an experimental study at high viscosities. J. Geophys. Res. Solid Earth 100, 4215-4229 (1995).

177. Caricchi, L. et al. Non-Newtonian rheology of crystal-bearing magmas and implications for magma ascent dynamics. Earth Planet. Sci. Lett. 264, 402-419 (2007).

178. Costa, A., Caricchi, L. \& Bagdassarov, N. A model for the rheology of particlebearing suspensions and partially molten rocks. Geochem. Geophys. Geosyst. 10 (2009).

179. Villemant, B. \& Boudon, G. Transition from dome-forming to plinian eruptive styles controlled by $\mathrm{H}_{2} \mathrm{O}$ and $\mathrm{Cl}$ degassing. Nature 392, 65-69 (1998).

180. Edmonds, M., Oppenheimer, C., Pyle, D. M., Herd, R. A. \& Thompson, G. $\mathrm{SO} 2$ emissions from Soufrière Hills Volcano and their relationship to conduit permeability, hydrothermal interaction and degassing regime. J. Volcanol. Geotherm. Res. 124, 23-43 (2003).

181. Castro, J. M., Bindeman, I. N., Tuffen, H. \& Ian Schipper, C. Explosive origin of silicic lava: textural and $\delta \mathrm{D}-\mathrm{H}_{2} \mathrm{O}$ evidence for pyroclastic degassing during rhyolite effusion. Earth Planet. Sci. Lett. 405, 52-61 (2014).

182. Saubin, E. et al. Conduit dynamics in transitional rhyolitic activity recorded by tuffisite vein textures from the 2008-2009 Chaitén Eruption. Front. Earth Sci. 4 (2016).

183. Lamur, A., Kendrick, J. E., Wadsworth, F. B. \& Lavallée, Y. Fracture healing and strength recovery in magmatic liquids. Geology 47, 195-198 (2019).

184. Hildreth, W., Halliday, A. N. \& Christiansen, R. L. Isotopic and chemical evidence concerning the genesis and contamination of basaltic and rhyolitic magma beneath the yellowstone plateau volcanic field. J. Petrol. 32, 63-138 (1991).

185. Gomberg, J., Bodin, P. \& Reasenberg, P. A. Observing earthquakes triggered in the near field by dynamic deformations. Bull. Seismol. Soc. Am. 93, 118-138 (2003).

186. Somerville, P. \& Yoshimura, J. The influence of critical Moho Reflections on strong ground motions recorded in San Francisco and Oakland during the 1989 Loma Prieta Earthquake. Geophys. Res. Lett. 17, 1203-1206 (1990).

187. Davis, P. M., Rubinstein, J. L., Liu, K. H., Gao, S. S. \& Knopoff, L. Northridge earthquake caused by geologic focusing of seismic waves. Science $\mathbf{2 8 9}$, 1746-1750 (2000).

188. Mori, J. \& Helmberger, D. Large-amplitude moho reflections (SmS) from Landers aftershocks, Southern California. Bull. Seismol. Soc. Am. 86, 1845-1852 (1996).

189. Hough, S. E. Remotely triggered earthquakes following moderate mainshocks (or, why California is not falling into the ocean). Seismol. Res. Lett. 76, 58-66 (2005).

190. Zhu, W., Ni, S., Zeng, X. \& Somerville, P. The contribution of postcritical moho reflections SmS to ground motions of the $2008 \mathrm{M}$ w 7.9 wenchuan earthquake. Bull. Seismol. Soc. Am. 109, 298-311 (2019).

191. Paolucci, R. Amplification of earthquake ground motion by steep topographic irregularities. Earthq. Eng. Struct. Dyn. 31, 1831-1853 (2002).

192. Langer, S., Finzi, Y. \& Olsen-Kettle, L. M. Dynamic triggering of earthquakes is promoted by crustal heterogeneities and bimaterial faults. Phys. Earth Planet. Inter. 238, 34-41 (2015).

193. Wallace, L. M. et al. Large-scale dynamic triggering of shallow slow slip enhanced by overlying sedimentary wedge. Nat. Geosci. 10, 765-770 (2017).

194. Farías, C., Galván, B. \& Miller, S. A. Numerical simulations (2D) on the influence of pre-existing local structures and seismic source characteristics in earthquake-volcano interactions. J. Volcanol. Geotherm. Res. 343, 192-210 (2017).

195. Biggs, J., Chivers, M. \& Hutchinson, M. C. Surface deformation and stress interactions during the 2007-2010 sequence of earthquake, dyke intrusion and eruption in northern Tanzania. Geophys. J. Int. 195, 16-26 (2013).

196. Kumagai, H. \& Chouet, B. A. Acoustic properties of a crack containing magmatic or hydrothermal fluids. J. Geophys. Res. Solid Earth 105, 25493-25512 (2000).

197. Nakano, M. \& Kumagai, H. Response of a hydrothermal system to magmatic heat inferred from temporal variations in the complex frequencies of longperiod events at Kusatsu-Shirane Volcano, Japan. J. Volcanol. Geotherm. Res. 147, 233-244 (2005).
198. Rudolph, M. L. \& Manga, M. Frequency dependence of mud volcano response to earthquakes. Geophys. Res. Lett. 39, 1-5 (2012).

199. Toda, S., Stein, R. S., Sevilgen, V. \& Lin, J. Coulomb 3.3 graphic-rich deformation and stress-change software for earthquake, tectonic, and volcano research and teaching - user guide. US Geol. Surv. Open-File Rep. 1060, 63 (2011).

200. Gabrieli, A., Wilson, L. \& Lane, S. Volcano-tectonic interactions as triggers of volcanic eruptions. Proc. Geol. Assoc. 126, 675-682 (2015).

201. Feuillet, N., Cocco, M., Musumeci, C. \& Nostro, C. Stress interaction between seismic and volcanic activity at Mt. Etna. Geophys. J. Int. 164, 697-718 (2006).

202. Walter, T. R. et al. Volcanic activity influenced by tectonic earthquakes: static and dynamic stress triggering at Mt. Merapi. Geophys. Res. Lett. 34, L05304 (2007).

203. Kriswati, E., Meilano, I., Iguchi, M., Abidin, H. Z. \& Surono An evaluation of the possibility of tectonic triggering of the Sinabung eruption. J. Volcanol. Geotherm. Res. 382, 224-232 (2019)

204. Kennedy, B. What effects do earthquakes have on volcanoes? Geology 45, 765-766 (2017)

205. Jolly, A., Lokmer, I., Christenson, B. \& Thun, J. Relating gas ascent to eruption triggering for the April 27, 2016, White Island (Whakaari), New Zealand eruption sequence. Earth Planets Space 70, 177 (2018).

206. Aizawa, K. et al. Gas pathways and remotely triggered earthquakes beneath Mount Fuji, Japan. Geology 44, 127-130 (2016).

207. Ozawa, T. \& Fujita, E. Local deformations around volcanoes associated with the 2011 off the Pacific coast of Tohoku earthquake. J. Geophys. Res. Solid Earth 118, 390-405 (2013).

208. Stein, R. S., Barka, A. A. \& Dieterich, J. H. Progressive failure on the North Anatolian fault since 1939 by earthquake stress triggering. Geophys. J. Int. 128, 594-604 (1997).

209. Potter, S. H., Jolly, G. E., Neall, V. E., Johnston, D. M. \& Scott, B. J. Communicating the status of volcanic activity: revising New Zealand's volcanic alert level system. J. Appl. Volcanol. 3, 1-16 (2014).

210. Davis, M., Koenders, M. A. \& Petford, N. Vibro-agitation of chambered magma. J. Volcanol. Geotherm. Res. 167, 24-36 (2007).

211. Sumita, I. \& Manga, M. Suspension rheology under oscillatory shear and its geophysical implications. Earth Planet. Sci. Lett. 269, 467-476 (2008).

212. Okubo, P. G. \& Wolfe, C. J. Swarms of similar long-period earthquakes in the mantle beneath Mauna Loa Volcano. J. Volcanol. Geotherm. Res. 178, 787-794 (2008).

213. Gottsmann, J., Lavallée, Y., Martí, J. \& Aguirre-Díaz, G. Magma-tectonic interaction and the eruption of silicic batholiths. Earth Planet. Sci. Lett. 284, 426-434 (2009).

214. Christopher, T. E. et al. Crustal-scale degassing due to magma system destabilization and magma-gas decoupling at Soufrière Hills Volcano, Montserrat. Geochem. Geophys. Geosyst. 16, 2797-2811 (2015)

215. Miyazawa, M. Propagation of an earthquake triggering front from the 2011 Tohoku-Oki earthquake. Geophys. Res. Lett. 38, 1-6 (2011).

216. Battaglia, J., Métaxian, J. P. \& Garaebiti, E. Earthquake-volcano interaction imaged by coda wave interferometry. Geophys. Res. Lett. 39, 4-7 (2012).

217. Rouwet, D. et al. Recognizing and tracking volcanic hazards related to nonmagmatic unrest: a review. J. Appl. Volcanol. 3, 1-17 (2014).

218. Phillipson, G., Sobradelo, R. \& Gottsmann, J. Global volcanic unrest in the 21st century: an analysis of the first decade. J. Volcanol. Geotherm. Res. 264, 183-196 (2013)

219. Yukutake, Y. et al. Remotely triggered seismic activity in Hakone volcano during and after the passage of surface waves from the 2011 M9.0 Tohoku-Oki earthquake. Earth Planet. Sci. Lett. 373, 205-216 (2013).

220. Lupi, M., Fuchs, F. \& Pacheco, J. F. Fault reactivation due to the M 7.6 Nicoya earthquake at the Turrialba-Irazú volcanic complex, Costa Rica: effects of dynamic stress triggering. Geophys. Res. Lett. 41, 4142-4148 (2014).

\section{Acknowledgements}

We thank Sriparna Saha for her help in improving the quality of the figures. G.S., B.K. and T.W. were supported by a Marsden grant. A.J. was funded by the Ministry of Business Innovation and Employment (MBIE) Strategic Science Investment Fund (SSIF)

\section{Author contributions}

G.S. drafted the initial MS and figures, with the participation of B.K. T.W. provided background on natural observations and statistical significance. M.I. provided background on physical mechanisms. A.J. provided seismological context. All authors contributed to the design of the ideas presented and the final version of the paper. 


\section{Competing interests}

The authors declare no competing interests.

\section{Additional information}

Correspondence and requests for materials should be addressed to G.S.

Peer review information Nature Communications thanks Michael Manga and the other, anonymous, reviewer for their contribution to the peer review of this work.

Reprints and permission information is available at http://www.nature.com/reprints

Publisher's note Springer Nature remains neutral with regard to jurisdictional claims in published maps and institutional affiliations. (c) (i) Open Access This article is licensed under a Creative Commons Attribution 4.0 International License, which permits use, sharing, adaptation, distribution and reproduction in any medium or format, as long as you give appropriate credit to the original author(s) and the source, provide a link to the Creative Commons license, and indicate if changes were made. The images or other third party material in this article are included in the article's Creative Commons license, unless indicated otherwise in a credit line to the material. If material is not included in the article's Creative Commons license and your intended use is not permitted by statutory regulation or exceeds the permitted use, you will need to obtain permission directly from the copyright holder. To view a copy of this license, visit http://creativecommons.org/ licenses/by/4.0/.

(C) The Author(s) 2021 